\title{
Who Draws the Maps and How? Experiments in Critical Mapping: Data, Scale and Functionalities
}

\author{
C.J. Alex* and T.V. Sajeev \\ Forest Protection Division, Kerala Forest Research Institute, Peechi, \\ Thrissur-680653, India \\ *Corresponding author
}

\section{A B S T R A C T}

\section{Keywords}

Critical mapping,

Institutionalized mapping,

Free \& open source GIS

software (FOSSGIS),

Web GIS

Article Info

Accepted:

04 October 2018

Available Online:

10 November 2018
Maps have long been identified as a political document aimed at structuring human senses, expectations, desire and notion on the space around. Developments in Geographic information technology which combines GIS, Remote Sensing and GPS has created new avenues in mapping and spatial decision making. Advent of FOSSGIS and Web GIS has further simplified data availability and analytical capability. These new technological advances have helped the use of critical mapping which is a set of new mapping practices and theoretical critique grounded in critical theory. It differs from academic cartography in that it links geographic knowledge with power structures operating in the area. The present study is a critical evaluation of traditional institutionalised maps and critical maps prepared by FOSSGIS and Web GIS techniques for three cases in Kerala. This critical mapping experiment reveals serious limitations of the existing State maps by way of the data it presents, the scale they use and the functionality it addresses. The present study demonstrates the use of new advancements in Geographic information technology can overcome these limitations reliably.

\section{Introduction}

Maps are graphic representations that facilitate a spatial understanding of things, concepts, conditions, processes, or events in the human world and it is one of the oldest forms of human communication (Harley and Woodward, 1987). It originated and evolved as a science and technology interface that primarily catered to the understanding, explaining and governing the geographical space around human beings. From oral maps of the nomadic tribes it has evolved in close association with various forms of governance systems whether they will be autocratic, colonial or democratic. However, when governance systems change, they move through a lag phase in which the change in theory is gradually converted to change in praxis like in the case of many colonial resource management norms continued to be in practice during the early phases of democracy.

Mapping still remains largely a State activity done by various departments of the State based on which important resource management decisions are made. In this study these institutional maps are compared based on three case studies with critical maps 
prepared using FOSSGIS and Web GIS techniques during the study. Critical mapping is a set of new mapping practices and theoretical critique grounded in critical theory which explicitly addresses the various sets of decisions taken during the mapping process as a function of existing power relations embedded in knowledge (Crampton, 2010). The main advantages of the critical mapping are that it uses available modern geographic data and technology which help to make largescale, updated, transparent and decentralised maps.

The first case is on land use mapping in Kavvai River basin, North Kerala in which the existing map was compared with the critical maps. The second case study mapped the quarries in Thrissur, Ernakulam and Palakkad districts and compared it with the existing institutional map and data. Thirdly, the study used change detection analysis of Mangroves in Ernakulam district using FOSSGIS, Web GIS and time series maps. The objective of the study was to evaluate the institutional and critical maps with regard to data, scale and their functionalities.

\section{Materials and Methods}

The most common and easy to use FOSSGIS software like Quantum GIS 2.8.1 (QGIS 2.8.1) was used for mapping and analysis. The Open access Web GIS like Google Earth, and Google Map were used for the study. The QGIS Open layer plug-in have a functionality to use online Google satellite image (Landsat8) as background layer for the spatial analysis at 1:2500 scale. The secondary GIS data layers used were Land use map prepared by Kerala State Land Use Board (KSLUB), drainage map (SOI, 1972), earthquake epicentre (Rajendran, et al., 2009), lineament (KSDMPP, 2010) spatial distribution map of minor mineral quarries prepared by Mining and Geology Directorate (M \& G Report
2014), environmental sensitive area (Gadgil et al., 2011; Kasthurirangan et al., 2013), Waste land atlas of India (2011), and elevation layer (USGS, 2004).

After detailed GPS field survey for locating geographical elements of enquiry, the survey points were brought into QGIS environment. Land class / objects in the satellite image (October 2013 and September 2002) and secondary geographic data were identified using this GPS point layer and vectorised as polygon shape file and finalised after detailed ground truthing. Spatial statistics of the mapped area was extracted as per Sarash and Monica (2002). The critical maps thus prepared and the extracted data was compared with the published maps and data of same area prepared by the corresponding government agency. The GIS analysis like intersection, Interpolation, Proximity analysis was done and final maps were prepared using Arc GIS 9.3 .

\section{Study area}

The first case study was conducted in Karuvellur Perealam panchayat of Kavvai River basin in north Kerala. This is a fragmented landscape with large expanse of lateritic biotope mediated by the Kavvai River which originates from midland literate hill at $160 \mathrm{msl}$ and empties into the Kavvayi estuary. In this area critical mapping and land use analysis was done during 2014. In the second case study, granite quarries in Thrissur, Palakkad and Ernakulam districts where stiff resistance has built from the general public against the quarries were mapped. The spatial information and proximity analysis results were compared with the map and data published by Kerala State Mining and Geology department (KSMGD).

According to the Survey of India's State of Forest Report - 2013 only two districts of 
Kerala, Kannur and Kasaragod possess mangrove cover $\left(6 \mathrm{~km}^{2}\right)$. This data is in stark contradiction with the report of Kerala Forest Department and the personal experience of the people who live in coastal zones of Kerala. The third case study critically analyse this problem through large scale mangrove distribution mapping in Ernakulam. The changes of mangroves in the Vypin area during $2002-2013$ were analysed.

\section{Results and Discussion}

\section{Case study 1: Land use mapping at Kavvai River basin}

The KSLUB map classifies the panchayat in to 9 land use classes (Fig. 1). The area wise list of each class is given in the Table 1. According to this map the largest land cover class is the coconut plantation which covers $60.7 \%$ of the total area and the smallest is built up land which covers $1.74 \%$.

According to waste land atlas of Kerala, waste land covers $3.97 \%$ of the area in the panchayat. Based on the map prepared in this study, there are 22 land use classes (Fig. 1 and Table 2). According to this map the largest land cover class is the homestead with mixed cultivation, which covers $39.9 \%$ of the total area. Laterite exposed area covers $4.76 \%$ of the panchayat.

The largest transect within the boundary polygon have a length of $9517.8 \mathrm{~m}$. In the KSLUB map, along the transect, seven land cover classes divide the transect into 45 segments. Standard deviation to the mean segment length of each cover classes is 68.54 and the Coefficients of variation (\%) are 271.65. In the case of the map prepared in the study, 16 land use classes along the largest transect divide it in to 125 segments. Standard deviation to the mean segment length of each cover classes is 30.06 and the coefficients of variation $(\%)$ are 318.88 .
According to the map prepared by the KSLUB of Karivallur- Peralam Panchayat, $60 \%$ of the area covered by Coconut plantation whereas this study shows only $7.46 \%$ of panchayat is under this land class. This difference could not have happened in the small period of 2 years between the preparations of these two maps. Interestingly, the latest map by KSLUB published after the preparation of the critical map during this study, the number of land classes is lower than the earlier map. There are 18 sacred groves (ranging from $0.1 \mathrm{~h}$ to $5.8 \mathrm{~h}$ ), mangrove vegetation, Kuthiru (Elevated lands in the centre or any corner of large paddy fields formed by depositing the extra soil during the old traditional paddy field levelling practice having natural or cultivated mixed vegetation.) and literate exposed area in the panchayat whereas these land classes are not only absent but got added up as mixed cultivation, agricultural fallow or waste land. The critical map shows that $4.68 \%$ of the study area is covered by ecologically and biodiversity rich lateritic exposed area evidenced by high biological endemism (Balakrishnan et al., 2010). The waste land atlas of India categorizes these areas as waste lands. An area of $10 \mathrm{~h}$ near to Kuniyan paddy field has been declared by the local people as Kuniyan bird sanctuary which harbors 86 bird species. The State mapping process had been insensitive to the local situations by way of inadequate data and inappropriate scale and pose great harm by classifying ecologically sensitive habitat patches as waste lands.

\section{Case study 2: Mapping of quarries in central Kerala}

We mapped 2168 quarries in the study area (Table 3), with quarries ranging in size from $0.2 \mathrm{~h}$ to $40 \mathrm{~h}$. Ninety percent of quarries belongs to area class $0.5 \mathrm{~h}$ to $5 \mathrm{~h}$. Drainage proximity analysis shows that there are 734 quarries within $100 \mathrm{~m}$ of first and second order drainage (Fig. 2). 
Fig.1 Comparison of land use map of Karivellur Peralam Panchayat

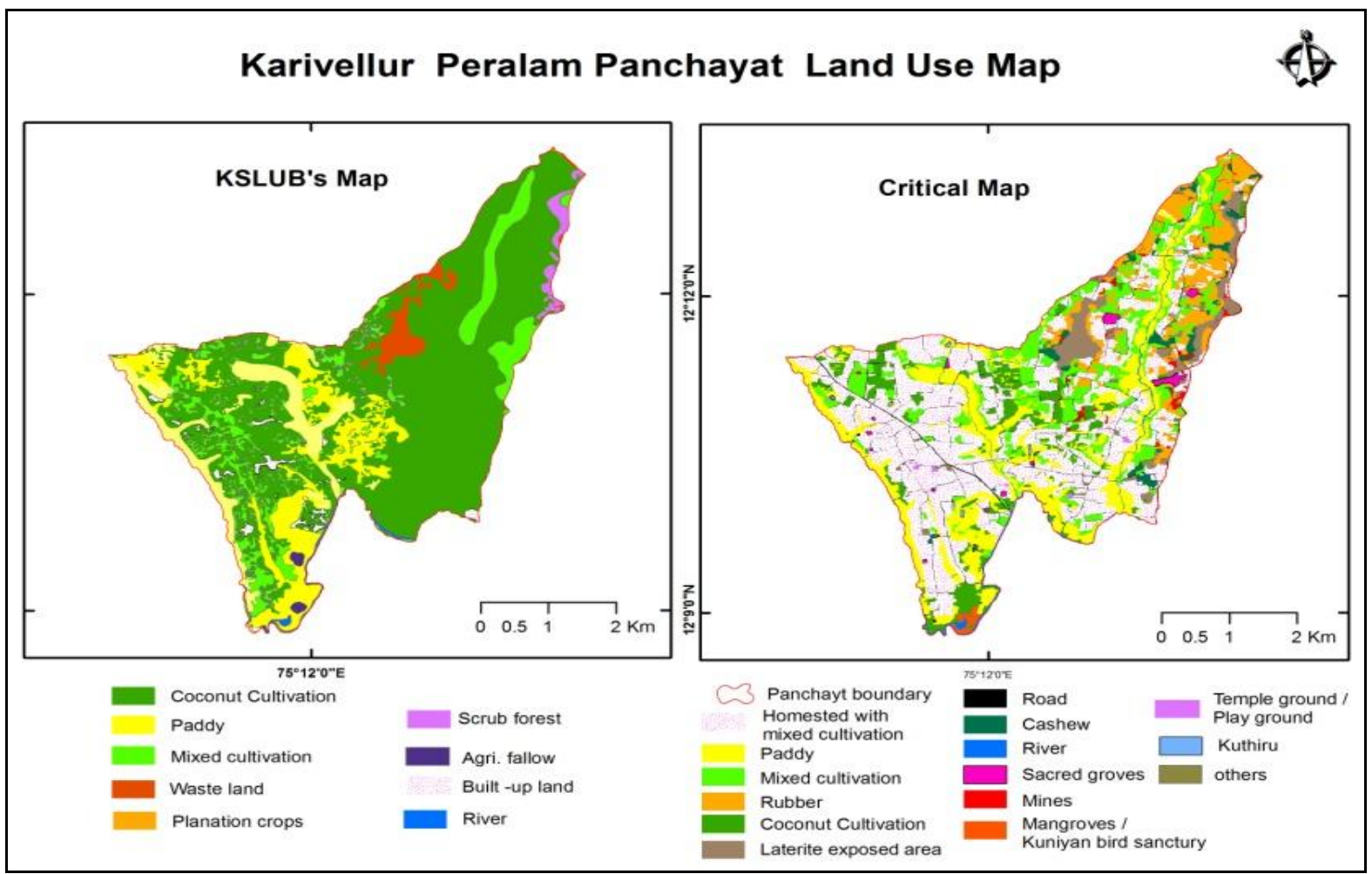

Fig.2 Comparison of quarries map

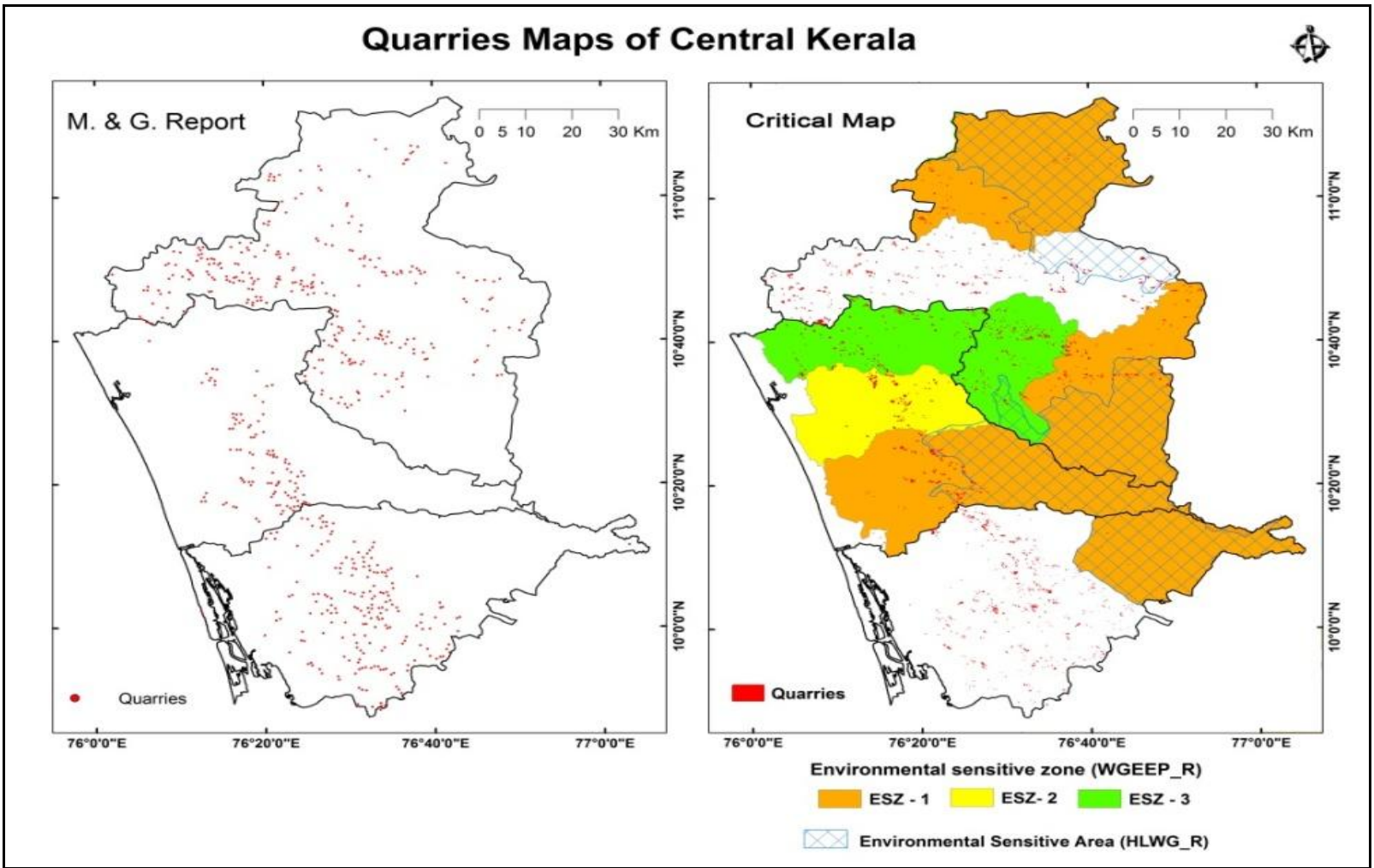


Fig.3 Land use change map of Vypin coastal region of Ernakulam during 2002 - 2013

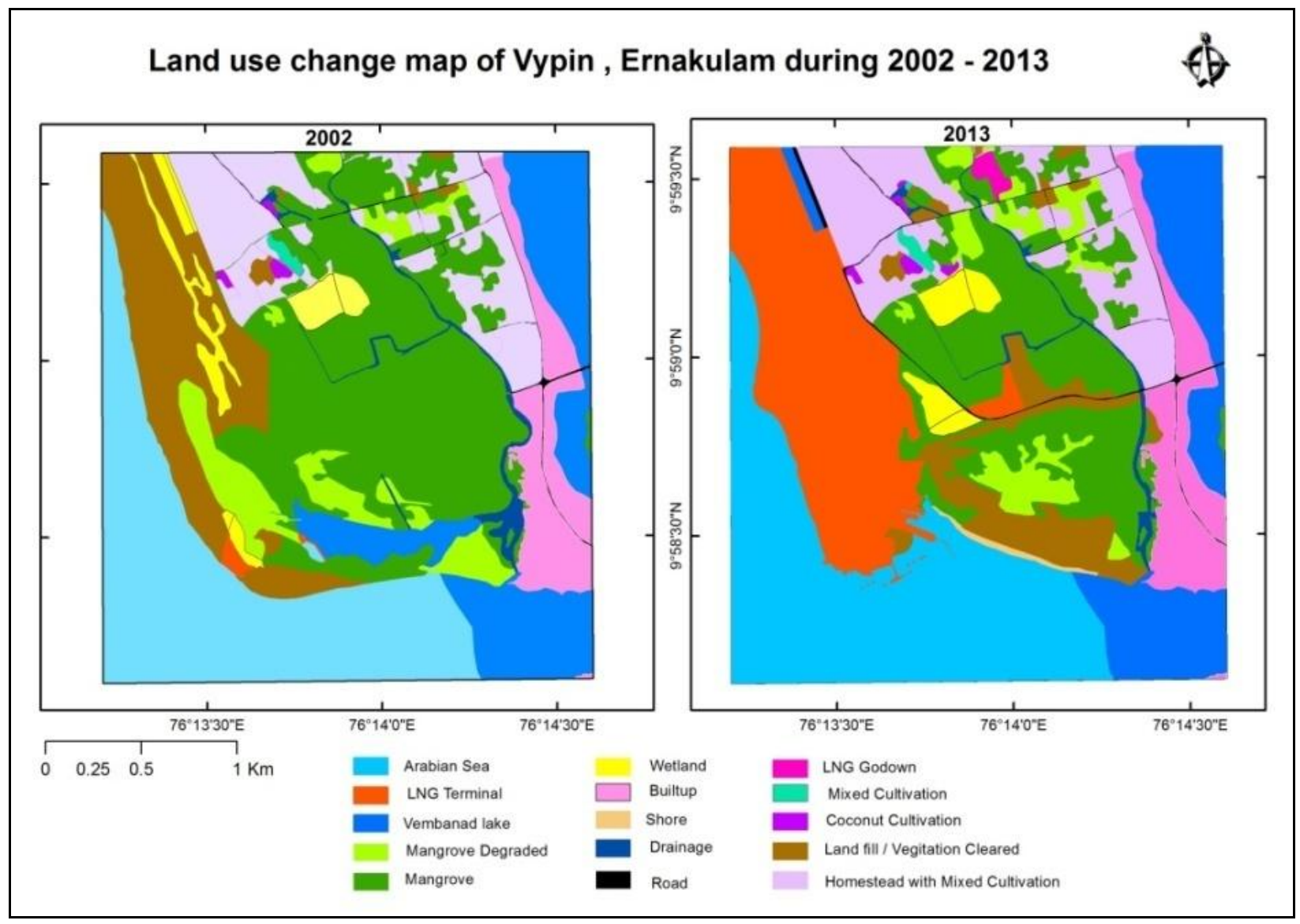

Table.1 Land use of the study area according to KSLUB Land use map - 2012

\begin{tabular}{|r|l|r|r|}
\hline Sl. No & \multicolumn{1}{|c|}{ Land use classes } & Area $\left(\mathrm{Km}^{2}\right)$ & Area percentage \\
\hline $\mathbf{1}$ & Coconut plantation & 13.98 & 60.65 \\
\hline $\mathbf{2}$ & Paddy & 4.46 & 19.41 \\
\hline $\mathbf{3}$ & Mixed Cultivation & 3.01 & 13.32 \\
\hline $\mathbf{4}$ & Wasteland & 0.62 & 2.67 \\
\hline $\mathbf{5}$ & Built up land (rural) & 0.40 & 1.74 \\
\hline $\mathbf{6}$ & Scrub forest & 0.30 & 1.30 \\
\hline 7 & Agricultural fallow & 0.07 & 0.24 \\
\hline $\mathbf{8}$ & Plantation crops & 0.07 & 0.04 \\
\hline $\mathbf{9}$ & River/ Stream perennial & 0.15 & 0.61 \\
\hline & & & 100 \\
\hline
\end{tabular}


Table.2 Land use of the study area 2014 through critical mapping methods

\begin{tabular}{|c|c|c|c|c|}
\hline & \multicolumn{2}{|c|}{ Land use/ land cover classes } & Area $\left(\mathrm{Km}^{2}\right)$ & Area Percentage \\
\hline 1 & \multicolumn{2}{|c|}{ Homestead with mixed cultivation } & 9.00 & 39.90 \\
\hline 2 & \multicolumn{2}{|c|}{ Paddy } & 3.98 & 17.26 \\
\hline \multirow[t]{3}{*}{3} & \multirow{3}{*}{$\begin{array}{l}\text { Mixed } \\
\text { Cultivation }\end{array}$} & - Arecanut & \multirow[t]{3}{*}{3.04} & \multirow[t]{3}{*}{14.05} \\
\hline & & $(43 \%)$ & & \\
\hline & & Others $(57 \%)$ & & \\
\hline 4 & \multicolumn{2}{|c|}{ Rubber Plantation } & 1.95 & 8.46 \\
\hline 5 & \multicolumn{2}{|c|}{ Coconut plantation } & 1.71 & 7.41 \\
\hline 6 & \multicolumn{2}{|c|}{ Laterite exposed area } & 1.08 & 4.68 \\
\hline 7 & \multicolumn{2}{|c|}{ Road Tarred road (70 \%), Mud road (30\%) } & 0.63 & 2.73 \\
\hline 8 & \multicolumn{2}{|c|}{ Cashew Plantation } & 0.42 & 1.82 \\
\hline 9 & \multicolumn{2}{|c|}{ River } & 0.33 & 1.43 \\
\hline 10 & \multicolumn{2}{|c|}{ Sacred groves } & 0.17 & 0.74 \\
\hline 11 & \multicolumn{2}{|c|}{ Mines } & 0.14 & 0.51 \\
\hline 12,13 & \multicolumn{2}{|c|}{ Mangroves / Kuniyan bird sanctuary } & 0.11 & 0.48 \\
\hline 14,15 & \multicolumn{2}{|c|}{ Temple ground / Play ground } & 0.11 & 0.48 \\
\hline 16 & \multicolumn{2}{|l|}{ Kuthiru } & 0.05 & 0.22 \\
\hline 17 & \multicolumn{2}{|c|}{ Riverine vegetation } & 0.024 & 0.09 \\
\hline 18 & \multicolumn{2}{|c|}{ Urban Built up } & 0.022 & 0.06 \\
\hline 19 & \multicolumn{2}{|c|}{ School \& School grounds } & 0.013 & 0.06 \\
\hline 20 & \multicolumn{2}{|l|}{ Cemetery } & 0.014 & 0.06 \\
\hline 21 & \multirow{2}{*}{\multicolumn{2}{|c|}{ Pond }} & 0.01 & 0.04 \\
\hline & & & 23.06 & 100 \\
\hline
\end{tabular}

Table.3 Number of Quarries in each class (The total area of quarry belonging to class is given in the bracket)

\begin{tabular}{|c|c|c|c|c|c|c|c|c|c|c|}
\hline \multirow[t]{2}{*}{ District } & \multirow{2}{*}{$\begin{array}{l}\text { Total no. } \\
\text { of } \\
\text { Quarries } \\
\text { (Critical } \\
\text { mapping) }\end{array}$} & \multirow{2}{*}{$\begin{array}{c}\text { Total no. of } \\
\text { Quarries } \\
\text { (KSMGDReport) }\end{array}$} & \multicolumn{2}{|c|}{$\begin{array}{l}\text { Lineament } \\
\text { Proximity }\end{array}$} & \multicolumn{2}{|c|}{$\begin{array}{l}\text { Epicentre } \\
\text { Proximity }\end{array}$} & \multicolumn{3}{|c|}{ WGEEP Report } & \multirow{2}{*}{$\begin{array}{c}\text { HLWG } \\
\text { Report } \\
\text { ESA }\end{array}$} \\
\hline & & & $\begin{array}{c}<200 \\
m\end{array}$ & $\begin{array}{l}200 \mathrm{~m}- \\
500 \mathrm{~m}\end{array}$ & $1<$ & $\begin{array}{l}1 \mathrm{~km}- \\
2 \mathrm{~km}\end{array}$ & $\begin{array}{c}\text { ESZ - } \\
1\end{array}$ & $\begin{array}{l}\text { ESZ - } \\
2\end{array}$ & $\begin{array}{c}\text { ESZ - } \\
3\end{array}$ & \\
\hline Palakkad & $\begin{array}{c}897 \\
(1278.6)\end{array}$ & 425 & $\begin{array}{c}19 \\
(32.0)\end{array}$ & $\begin{array}{c}28 \\
(22.5)\end{array}$ & $\begin{array}{c}5 \\
(2.74)\end{array}$ & $\begin{array}{c}10 \\
(6.9)\end{array}$ & $\begin{array}{c}288 \\
(333.8)\end{array}$ & - & $\begin{array}{c}229 \\
(253.2)\end{array}$ & $\begin{array}{c}127 \\
(197.9)\end{array}$ \\
\hline Ernakulam & $\begin{array}{c}795 \\
(1187.9)\end{array}$ & 691 & $\begin{array}{c}60 \\
(42.6)\end{array}$ & $\begin{array}{c}101 \\
(90.1)\end{array}$ & $\begin{array}{c}14 \\
(18.6)\end{array}$ & $\begin{array}{c}49 \\
(40.5)\end{array}$ & $\begin{array}{c}10 \\
(6.7)\end{array}$ & - & - & $\begin{array}{c}64 \\
(83.1)\end{array}$ \\
\hline Thrissur & $\begin{array}{c}476 \\
(871.2)\end{array}$ & 323 & $\begin{array}{c}29 \\
(31.2)\end{array}$ & $\begin{array}{c}58 \\
(71.9)\end{array}$ & $\begin{array}{c}23 \\
(33.7)\end{array}$ & $\begin{array}{c}47 \\
(64.3)\end{array}$ & $\begin{array}{c}153 \\
(279.3)\end{array}$ & $\begin{array}{c}106 \\
(274.5)\end{array}$ & $\begin{array}{c}215 \\
(310.3)\end{array}$ & $\begin{array}{c}10 \\
(6.7)\end{array}$ \\
\hline Total & $\begin{array}{c}2168 \\
(3337.7)\end{array}$ & 1439 & $\begin{array}{c}108 \\
(105.7)\end{array}$ & $\begin{array}{c}187 \\
(184.5)\end{array}$ & $\begin{array}{c}42 \\
(55.1)\end{array}$ & $\begin{array}{c}106 \\
(111.7)\end{array}$ & $\begin{array}{c}451 \\
(619.7)\end{array}$ & $\begin{array}{c}106 \\
(274.5\end{array}$ & $\begin{array}{c}444 \\
(563.5)\end{array}$ & $\begin{array}{c}201 \\
(287.6)\end{array}$ \\
\hline
\end{tabular}


Table.4 Changes of mangrove during $2002-2013$

\begin{tabular}{|c|l|r|r|}
\hline Sl. no & \multicolumn{1}{|c|}{ Land use type } & Area (h) & Area percentage \\
\hline $\mathbf{1}$ & Mangrove (no change) & 121.99 & 53.02 \\
\hline $\mathbf{2}$ & Land fill or vegetation cleared & 36.15 & 15.71 \\
\hline $\mathbf{3}$ & Mangrove degraded area & 25.73 & 11.18 \\
\hline $\mathbf{4}$ & LNG Terminal & 32.15 & 13.97 \\
\hline $\mathbf{5}$ & Others & 11.1 & 5.08 \\
\hline $\mathbf{6}$ & Road & 2.29 & 1.00 \\
\hline
\end{tabular}

Ninety percent of the quarries are in the elevation range $25 \mathrm{~m}$ to $150 \mathrm{~m}$ from mean sea level which indicates that the midland hillocks are the most impacted. District wise lineament and epicentre proximity of the quarries are given in Table 3. Number of the quarries falling in the Environmental sensitive area according to Western Ghats Ecology and Expert Panel (WGEEP) report and High Level Working Group (HLWG) report is given in Table 3.

M\&G Reports have the point layer representation of 1439 quarries whereas the present study mapped 2168 quarries as polygon layers in the study area. Midland hills are the integral part of the landscape of Kerala critical to ground water conservation, micro climate maintenance and biodiversity conservation. The study shows that the quarries have disrupted the undulation of the midland hills and drainage network of the area. There are many scientific studies which prove the relationship between quarrying and lineament tectonics, slope instability and small scale seismicity (Quido and Mencl 1982).

In the study area, 108 quarries are within $200 \mathrm{~m}$ from lineaments and 42 are within $1 \mathrm{~km}$ from recorded earthquake epicentres. Twenty six percent of the total quarries are in the Environmental sensitive Zone 1 and 2 of the WGEEP report where as $9.2 \%$ of total quarries are in Environmental Sensitive Area of the HLWG report. The results show serious concerns regarding the functionality of the $M \& G$ map and data. Beyond giving the point information on the location of a quarry the information provides no information which would help local decision making on resource use, impact and much needed disaster preparedness.

\section{Case Study 3: Change analysis of Mangroves in Ernakulam district}

The present study mapped 105 mangrove patches with an area greater than $1 \mathrm{~h}$ per patch. The total mangrove area covers $443 \mathrm{~h}$ in the study area. There are 9 patches in the area that are greater than $10 \mathrm{~h}$. There were $229.41 \mathrm{~h}$ of mangrove in the Vypin coastal region of Ernakulam during 2002 whereas $43 \%$ (107 h) of the mangrove have been converted to other land uses during $2002-2013$ (Table 4). Along with mangroves, other natural land covers like wet lands and drainage have had abrupt change in the area. The drainage course has been changed due to human intervention and $10 \mathrm{~h}$ of Vembanad Lake which is a Ramsar site has been filled mostly with dredged silt (Fig. 3).

This critical mapping experiment using the three cases detailed above reveals serious limitations of the existing State maps by way of data it presents, the scale they use and the functionalities it addresses. Changing from low resolution coarse data to high resolution finer data, using large scale maps instead of low scale maps, use of polygon data representation instead of point data in cases where the mapping element possess area and specifically fixing the functional use while preparing the 
map are critical changes needed in the use of GIS, Remote Sensing and ground truthing in a high population density State like Kerala. As a technology which closely assisted governance systems, this technology has not yet been used to its real potential in helping the decentralised governance system in Kerala. As the case studies show, this is practical with the use of new advancements in GIS and Remote Sensing.

\section{Acknowledgements}

The authors are thankful to the Kerala State Council for Science, Technology, and Environment, Government of Kerala for providing financial support. Thanks to Dr. Sreejith K.A., Vimod K. K., and Prajth M P for their help and support.

\section{References}

Balakrishnan V.C., Palot M. J., and Rajesh K. P., 2010. Observations on the flora of Madayipara a midland laterite hill in Kannur district, Kerala. Malabar Trogon 8, 14-29

Gadgil, M., Krishnan, B.J., Ganeshaiah, K.N., Vijayan, V.S., Borges, R., Sukumar, R., Noronha, L., Nayak, V.S., Subramaniam, D.K., Varna, R.V. and Gautam, S.P., 2011. Report of the Western Ghats ecology expert panel. Submitted to the Ministry of Environment and Forests, Government of India. Pp. 20 - 29

Harley, J. B., and Woodward, D., 1987. Preface, Cartography in Prehistoric, Ancient, and Medieval Europe and the Mediterranean. University of Chicago Press. Chicago. Pp $1-8$

Huang, R., and Chan, L., 2004. Human induced landslides in China, Chinese Journal of
Rock mechanics and Engineering 23(16), 66-77

Jermy, W. C., 2010. Mapping, a critical introduction to cartography and GIS, Wiley Blackwell publications, London Pp. $21-35$.

Kasturirangan, K., Babu, C.R., Mauskar, J.M., Chopra, K., Kishwan, J., Shankar, D., Narain, S., Roy, P.S., Tyagi, A. and Chandrasekharan, I., 2013. Report of the high level working group on Western Ghats. Submitted to the Ministry of Environment and Forests, Government of India. Pp.73 - 88

KSDMPP, 2010. Kerala State Disaster Management Plan Profile, Kerala State Disaster Management Authority, Government of Kerala. Pp. 20-24.

M \& G Report., 2014. Spatial Distribution map of minor mineral Quarries in Kerala, GIS Laboratory, directorate of Mining \& Geology, Government of Kerala.

Quido, Z., and Vogtech, M., 1982. Landslides and their control, Elsevier scientific publishing company, Amsterdam, New York. Pp. $102-115$

Rajendran C. P., Baiju, M J., Sreekumary, K., and Kusala, R., 2009. Reassessing the Earthquake Hazard in Kerala Based on the Historical and Current Seismicity. J. geological society of India. 73, 785-802

Sarah, E. G., and Monica G. T., 2002. Learning landscape ecology, A practical guide to concepts and techniques. Spinger-verlag publishers, New York, Pp. 3-9.

SOI, Toposheet, Survey of India, 1972. Government of India.

USGS (2004) Shuttle Radar Topography Mission, 1 Arc Second scene

Waste land atlas of India, 2011. Department of Land Resources, Ministry of Rural Development, New Delhi, Pp 115-125

\section{How to cite this article:}

Alex, C.J. and Sajeev, T.V. 2018. Who Draws the Maps and How? Experiments in Critical Mapping: Data, Scale and Functionalities. Int.J.Curr.Microbiol.App.Sci. 7(11): 213-220. doi: https://doi.org/10.20546/ijcmas.2018.711.026 